\title{
Ecology of Nymphaea pubescens Willd.
}

\author{
Umesh Koirala \\ Department of Botany, Post Graduate Campus, T.U., Biratnagar, Nepal \\ *E-mail: umesh6977@hotmail.com
}

\begin{abstract}
In an aged shallow pond at Biratnagar, Nepal, importance value index of Nymphaea pubescens ranged between 258 (July) and 75 (October). The productivity of the Nymphaea association was $681.6 \mathrm{~g} / \mathrm{m}^{2} / \mathrm{yr}$. The water samples had higher values of $\mathrm{pH}$, nitrogen and ammonia in June (initial phase of growth), but higher values of electrical conductivity, dissolved solids, turbidity, nitrite, nitrate, phosphorus and potassium in November (senescence phase of the plant). The $\mathrm{C} / \mathrm{N}$ ratio of the base-layer soil was 15.79:1 in June, but 17.27:1 in November. In comparison to other plant parts, highest concentrations of nitrogen (3.73\% in July), and potassium ( $2.04 \%$ in August) occurred in leaves; and phosphorus (1.4\% in September) in rhizome and roots. Fresh seeds had $90 \%$ germination and 8 month old air-dried rhizomes had $86 \%$ sprouting when immersed in water.
\end{abstract}

Key words: Biomass, germination, nutrient, productivity, rhizome.

\section{Introduction \\ Nymphaea rubra Roxb. ex Andrews}

Nymphaea pubescens Willd. (Nymphaea rubra Roxb. ex Andrews) of the family Nymphaeaceae is a floating-leaved rhizomatous herbs. It mostly grows in shallow water. It is distributed in south and south-east Asia (including Bangladesh, India, Java, Malaysia, Nepal, Pakistan, Philippines, Sri Lanka), Africa and Hungary (Panda \& Das, 2004). In Nepal, it is called 'Koka', 'Bhentha', or 'Seto-kamal' and occurs between altitude 60 to 500 $\mathrm{m}$ (Jha \& Jha 2000). At Biratnagar ( lat. N $26^{\circ} 20^{\prime}$, long. E $87^{\circ} 16^{\prime}$; altitude $72 \mathrm{~m}$, msl), the plant sproutes from rhizome in June and enteres into flowering-fruiting phase in August. After maturation of seeds in September-October, the plant enteres into the senescence phase in October-November. N. pubescens is a fragrant night-flowering species. The rhizomes with root are eaten as vegetables; the leaves are used as fodder. Most parts of the plant are used medicinally.

The present study deals with monthly variations in importance value index (IVI), diversity indices, and biomass of $N$. pubescens and associated species occurring in an aged shallow pond (area $150 \times 50 \mathrm{~m}$; depth of water in centre 1.2 during rainy season) at Biratnagar (retaining water only during the rainy season) along with monthly changes in concentrations of nitrogen, phosphorus and potassium in different parts of the plant and physico-chemical properties of water and mud of the pond. In general, climate of Biratnagar is tropical and monsoonic with three distinct seasons viz, rainy (mid-June to October), winter (November to February), and summer (March to mid-June). Average meteorological data indicate 1225,5 , and $188 \mathrm{~mm}$ rainfall; $25,10.4$ and $19.6^{\circ} \mathrm{C}$ minimum air temperature; $32.2,25$ and $33.6^{\circ} \mathrm{C}$ maximum air temperature; and $6,3.8$ and $7.3 \mathrm{~km} / \mathrm{h}$ wind speed during rainy, winter and summer season, respectively. 


\section{Materials and Methods}

Nymphaea pubescens and the associated species of the shore area $(20 \mathrm{~cm} 1.2 \mathrm{~m}$ to water depth) were sampled by laying ten quadrats of $50 \times 50 \mathrm{~cm}$ size randomly for determination of IVI, diversity indices, and biomass at monthly intervals (first week of July, August, September and October) in 2011. The IVI was calculated as the sum of relative frequency, relative density and relative cover (Curtis and McIntosh 1951), and diversity indices were determined as per the method of Simpson (1949), and Shannon \& Weaver (1949). The net primary productivity (NPP) was calculated by summing the positive increments in dry biomass on successive sampling dates (Singh \& Yadava 1974). The turnover rate was determined as per the method of Dahlman \& Kucera (1965) as $\mathrm{T}=\mathrm{A} / \mathrm{B}$, where, $\mathrm{T}=$ turnover rate, $\mathrm{A}=\mathrm{NPP}, \mathrm{B}=$ maximum biomass; and turnover time as: $1 / \mathrm{T} \times 12$.

Seeds of Nymphaea pubescens were collected from pond (Kanchanbari, Biratnagar) in the last week of September, 2010. Those seeds were evaluated for germination immediately after collection. As seeds did not germinate on filter paper saturated with distilled water, seeds (25) were placed in $500 \mathrm{ml}$ beakers (in triplicate) filled with distilled water, and kept as such until germination became static.

Plant and mud samples were analysed for nitrogen by Nessler's reagent method (Willard et at., 1974), phosphorus by chlorostannous-reduced molybdophosphoric blue color method (Furman, 1962), and potassium by flame photometer method (Piper, 1944). The texture of the mud was determined by sieving and weighing method (Piper, 1944), and organic carbon by Walkley and Black (1934) method.

Among the physico-chemical parameters of water samples, $\mathrm{pH}$ was determined by digital pH meter; conductivity by electrical conductivity meter (Willard et al., 1974); turbidity (nephelometric method), phosphorus (vandomolybdo-phospheric acid colorimetric method), total nitrogen (macro Kjeldahl method), nitrate and nitrite (UV spectrophotometric method), and potassium (atomic absorption spectrophoto-metric method) by APHA's (1990) methods; and total dissolved solids by the method of U.S. Geological Survey (1974).

\section{Results and Discussion \\ IVI, diversity indices, biomass and productivity}

Nymphaea pubescens completed its life-cycle between July to October (rainy season) and during this period IVI of $N$. pubescens decreased from 258 in July to merely 75 in October (Table 1). Only Marsilea minuta (IVI 42) was present in association with $N$ pubescens in July, whereas 6, 4, and 7 species were present in association in August, September and October, respectively. The species next to $N$. pubescens in IVI value were Eichhornia crassipes (55) and Panicum paludosum (40) in August; Utricularia aurea (95), P. paludosum (590) and E. crassipes (34) in September; and. U. aurea (68), E. crassipes (66) and P. paludosum (37) in October.

The values of Simpson's and Shannon-Weiner's index of diversity were minimum $(0.24$ and 0.40 , respectively) in July and maximum ( 0.81 and 1.76 , respectively) in October (Table 1). 
Table 1. Monthly variations in IVI (mean \pm SE; $n=10$ ) of macrophytes and diversity indices in Nymphaea pubescens association

\begin{tabular}{lllll}
\hline & July & August & September & October \\
\hline IVI & & & & \\
Alternanthera philoxeroides & - & $16 \pm 1$ & - & $13 \pm 1$ \\
Eichhornia crassipes & - & $55 \pm 3$ & $34 \pm 2$ & $66 \pm 3$ \\
Ipomoea aquatica & - & - & - & $11 \pm 1$ \\
Leersia hexandra & - & $29 \pm 2$ & - & - \\
Marsilea minuta & $42 \pm 2$ & - & - & $30 \pm 2$ \\
Nymphaea pubescens & $258 \pm 7$ & $143 \pm 5$ & $112 \pm 5$ & $75 \pm 4$ \\
Panicum paludosum & - & $40 \pm 2$ & $59 \pm 3$ & $37 \pm 2$ \\
Sacciolepis indica & - & $17 \pm 1$ & - & - \\
Utricularia aurea & - & - & $95 \pm 4$ & $68 \pm 3$ \\
\hline Diversity indices & & & & \\
Simpson's index & 0.24 & 0.70 & 0.71 & 0.81 \\
Shannon-Weiner's index & 0.40 & 1.11 & 1.29 & 1.76 \\
\hline
\end{tabular}

The biomass of $N$. pubescens ranged between 52 (July) and $413.6 \mathrm{~g} / \mathrm{m}^{2}$ (September) (Table 2). The species next to $N$. pubescens in biomass value were Marsilea minuta $\left(5.2 \mathrm{~g} / \mathrm{m}^{2}\right)$ and Sacciolepis indica $\left(10.4 \mathrm{~g} / \mathrm{m}^{2}\right)$ in July and August, respectively; Utricularia aurea (44 $\left.\mathrm{g} / \mathrm{m}^{2}\right)$ and Panicum paludosum $\left(41.6 \mathrm{~g} / \mathrm{m}^{2}\right)$ in September; and Eichhornia crassipes (193.6 $\left.\mathrm{g} / \mathrm{m}^{2}\right)$, U. aurea $\left(100.8 \mathrm{~g} / \mathrm{m}^{2}\right)$ and $P$. paludosum $\left(76.8 \mathrm{~g} / \mathrm{m}^{2}\right)$ in October.

Table 2. Monthly variations in biomass $\left(\mathrm{g} / \mathrm{m}^{2}\right)$ (mean $\left.\pm \mathrm{SE} ; \mathrm{n}=3\right)$ in Nymphaea pubescens and associated species

\begin{tabular}{lllll}
\hline Species & July & August & September & October \\
\hline Alternanthera sessilis & - & $1.60 \pm 0.56$ & - & $1.60 \pm 0.56$ \\
Eichhornia crassipes & - & $1.60 \pm 0.56$ & $1.60 \pm 0.56$ & $193.60 \pm 6.22$ \\
Ipomoea aquatica & - & - & - & $6.40 \pm 1.13$ \\
Leersia hexandra & - & $0.40 \pm 0.28$ & - & - \\
Marsilea minuta & $5.20 \pm 1.02$ & - & - & $21.60 \pm 2.08$ \\
Nymphaea pubescens & $52.00 \pm 3.22$ & $408.00 \pm 9.03$ & $413.60 \pm 9.09$ & $245.6 \pm 7.01$ \\
Panicum paludosum & - & $5.60 \pm 1.06$ & $41.60 \pm 2.88$ & $76.80 \pm 3.92$ \\
Sacciolepis indica & - & $10.40 \pm 1.44$ & - & - \\
Utricularia aurea & - & - & $44.00 \pm 2.97$ & $100.80 \pm 4.49$ \\
\hline Total & 57.20 & 427.60 & 500.80 & 646.40 \\
\hline
\end{tabular}

The productivity of $N$. pubescens association was $681.6 \mathrm{~g} / \mathrm{m}^{2} / \mathrm{yr}$ in which percentage contributions of the associated species were in the order: $N$. pubescens $(53)>$ E. crassipes (28) $>$ P. paludosum (10) $>U$. aurea (8) $>$ others (1) (Table 3). The turnover rate of $N$. pubescens was $87.42 \%$ and turnover time 14 months. On the other hand, turnover rate and turnover time of $E$. crassipes were $99.17 \%$ and 12 months, respectively and that of $P$. paludosum $92.70 \%$ and 13 months, respectively (Table 3 ).

Table 3. Productivity, turnover rate and turnover time of major macrophytes in Nymphaea pubescens association

\begin{tabular}{lccc}
\hline Macrophytes & Productivity (g/m²/yr) & Turnover rate (\%) & Turnover time (months) \\
\hline Eichhornia crassipes & 192.00 & 99.17 & 12 \\
Nymphaea pubescens & 361.60 & 87.42 & 14 \\
Panicum paludosum & 71.20 & 92.70 & 13 \\
Utricularia aurea & 56.80 & - & - \\
\hline
\end{tabular}




\section{Nutrirnts}

The range of nitrogen concentration was between 1.84 (July) and 3.64\% (October) in rhizome and roots, and between 1.93 (October) and 3.73\% (July) in leaves, whereas nitrogen concentration in flowers and seeds was 1.89 and $1.64 \%$, respectively (Table 4).

Table 4. Monthly variations in percentage concentration of nitrogen, phosphorus and potassium in different parts of Nymphaea pubescens (mean $\pm \mathrm{SE} ; \mathrm{n}=3$ )

\begin{tabular}{llllllllllllll}
\hline & \multicolumn{3}{c}{ July } & \multicolumn{4}{c}{ August } & \multicolumn{3}{c}{ Sept } & \multicolumn{3}{c}{ October } \\
\cline { 2 - 13 } & & $\mathbf{N}$ & $\mathbf{P}$ & $\mathbf{K}$ & $\mathbf{N}$ & $\mathbf{P}$ & $\mathbf{K}$ & $\mathbf{N}$ & \multicolumn{1}{c}{$\mathbf{P}$} & \multicolumn{1}{c}{ K } & \multicolumn{1}{c}{$\mathbf{N}$} & \multicolumn{1}{c}{$\mathbf{P}$} & \multicolumn{1}{|}{ K } \\
\hline Rhizome & 1.84 & 1.00 & 1.25 & 2.27 & 0.85 & 1.75 & 2.17 & 1.40 & 2.00 & 3.64 & 0.57 & 0.75 \\
and roots & \pm 0.78 & \pm 0.57 & \pm 0.64 & \pm 0.86 & \pm 0.52 & \pm 0.76 & \pm 0.84 & \pm 0.67 & \pm 0.81 & \pm 1.10 & \pm 0.43 & \pm 0.50 \\
\hline Leaves & 3.73 & 1.10 & 1.95 & 2.84 & 2.04 & 0.47 & 2.27 & 0.65 & 0.75 & 1.93 & 0.57 & 1.90 \\
& \pm 1.11 & \pm 0.60 & \pm 0.80 & \pm 0.69 & \pm 0.96 & \pm 0.82 & \pm 0.86 & \pm 0.45 & \pm 0.50 & \pm 0.80 & \pm 0.43 & \pm 0.79 \\
\hline Flowers & - & - & - & - & - & - & - & - & - & 1.89 & 0.39 & 1.25 \\
& & & & & & & & & & & \pm 0.79 & \pm 0.36 & \pm 0.64 \\
\hline Seeds & - & - & - & - & - & - & - & - & - & 1.64 & 0.36 & 0.50 \\
& & & & & & & & & & & \pm 0.73 & \pm 0.34 & \pm 0.40 \\
\hline
\end{tabular}

\section{Germination}

Seeds of Nymphaea pubescens were round in shape, pink to black in colour, and weight of 500 fresh seeds was $1.15 \mathrm{~g}$. Fresh seeds of both species started germinating three days after submergence in water and germination became static after $8^{\text {th }}$ day of submergence. In general, total germination of seeds was $90 \%$.

\section{Pond water and mud}

The $\mathrm{pH}$ value of water samples of $N$. pubescens association was more (6.33) in June than November (5.93). Otherwise, values of conductivity $(170 \mathrm{ds} / \mathrm{m})$, turbidity (24 NTU) and total dissolved solids $(85.3 \mathrm{mg} / \mathrm{l})$ were more in November than June (Table 4). Total nitrogen $(4.37 \mathrm{mg} / \mathrm{l})$ and ammonia $(1.17 \mathrm{mg} / \mathrm{l})$ contents of water samples were more in June, whereas water samples had higher concentrations of nitrate $(0.05 \mathrm{mg} / \mathrm{l})$, nitrite $(0.01$ $\mathrm{mg} / \mathrm{l})$, phosphorus $(1.12 \mathrm{mg} / \mathrm{l})$ and potassium $(44 . .3 \mathrm{mg} / \mathrm{l})$ in November than June.

The $\mathrm{pH}$ of the mud samples of $N$. pubescens association was 5.9 in June but 5.8 in November (Tables 5, 6). The mud was silty-sandy loam in which proportion of sand and clay particles decreased but silt particles increased slightly in November than June. There was no change in phosphorus concentration $(0.003 \%)$ between June and November but a slight increase in nitrogen and potassium concentration was noted in November. The range of organic carbon was 3 (June) and 4.49\% (November), whereas C/N ratio was 15.79:1 in June but 17.27:1 in November.

Table 5. Variations in physico-chemical properties of water before emergenc (June) and after senescence (November) of Nymphaea pubescens(mean $\pm \mathrm{SE}$; $\mathrm{sn}=3$ )

\begin{tabular}{lcc}
\hline & June & November \\
\hline $\mathrm{pH}$ & $6.33 \pm 1.45$ & $5.93 \pm 1.40$ \\
Conductivity $(\mathrm{ds} / \mathrm{m})$ & $103.40 \pm 5.87$ & $170.90 \pm 7.54$ \\
Turbidity (NTU) & $2.86 \pm 0.97$ & $24.00 \pm 2.82$ \\
Total dissolved solids $(\mathrm{mg} / \mathrm{l})$ & $51.00 \pm 4.12$ & $85.30 \pm 5.32$ \\
Total nitrogen $(\mathrm{mg} / \mathrm{l})$ & $4.37 \pm 1.20$ & $0.98 \pm 0.56$ \\
Ammonia $(\mathrm{mg} / \mathrm{l})$ & $1.17 \pm 0.62$ & $0.38 \pm 0.34$ \\
Nitrate $(\mathrm{mg} / \mathrm{l})$ & $0.01 \pm 0.05$ & $0.05 \pm 0.12$ \\
Nitrite $(\mathrm{mg} / \mathrm{l})$ & $0.001 \pm .03$ & $0.01 \pm 0.01$ \\
Total phosphorus $(\mathrm{mg} / \mathrm{l})$ & $0.39 \pm 0.36$ & $1.12 \pm 0.60$ \\
Potassium $(\mathrm{mg} / \mathrm{l})$ & $5.81 \pm 1.38$ & $44.30 \pm 3.89$ \\
\hline
\end{tabular}


Table 6. Variations in physico-chemical properties of mud before emergence (June) and after senescence (November) of Nymphaea pubescens (mean $\pm \mathrm{SE}$; $\mathrm{n}=3$ ) (Table 6 is not mentioned in the text)

\begin{tabular}{lll}
\hline & June & November \\
\hline $\mathrm{pH}$ & $5.9 \pm 1.40$ & $5.8 \pm 1.38$ \\
\hline Texture (\%) & $37.1 \pm 3.51$ & $30.7 \pm 3.19$ \\
Sand & $42.7 \pm 3.76$ & $50.8 \pm 4.11$ \\
Silt & $20.2 \pm 2.58$ & $18.5 \pm 2.48$ \\
Clay & & \\
\hline Nutrients $(\%)$ & $0.19 \pm 0.24$ & $0.26 \pm 0.28$ \\
$\mathrm{~N}$ & $0.003 \pm 0.03$ & $0.003 \pm 0.03$ \\
$\mathrm{P}$ & $0.01 \pm 0.10$ & $0.04 \pm 0.03$ \\
$\mathrm{~K}$ & $3.00 \pm 1.00$ & $4.49 \pm 1.22$ \\
\hline Organic carbon $(\%)$ & $5.79: 1$ & $17.27: 1$ \\
\hline C/N ratio & & \\
\hline
\end{tabular}

\section{Acknowledgements}

Thanks are due to National Agricultural Research Council (NARC), Khumaltar, Lalitpur and SEAM-N (Strengthening of the Environmental Adminstration and Management at the local level, Nepal), Biratnagar for lab facilities.

\section{Reference}

APHA (American Public Health Association) 1990. Standard Methods for the Examination of water and waste water, $16^{\text {th }}$ edn. APHA, Inc., New York

Curtis, J.T. \& R.P. McIntosh 1951. An upland forest continuum in the prairie-forest border region of Wisconsin. Ecology 32: 476-498.

Dahlman, R.C. \& C.L. Kucera 1965. Root productivity and turnover in native prairie. Ecology 46: $84-89$

Furman, N.H. (ed.) 1962. Standard Methods of Chemical Analysis, $6^{\text {th }}$ edn. D. Van Nostrand Co., New Jersey, USA.

Jha, S. \& P.K. Jha 2000. Contribution to the flora of Morang district and adjoining areas of Nepal. LIDIA 5 (1-2): 25-64.

Panda, S. \& A.P. Das 2004. Flora of Sambalpur (Orissa). Bishen Singh Mahendra Pal Singh, Dehra Dun, India.

Piper, C.S. 1944. Soil and Plant Analysis. The University of Adelaide, Australia.

Shannon, C.E \& W. Weaver 1949. The Mathematical Theory of Communication. University of Illinois Press, Urbana, USA.

Simpson, E.H. 1949. Measurements of diversity. Nature 163: 688.

Singh, J.S. \& P.S. Yadava 1974. Seasonal variations in composition, plant biomass and net primary productivity of a tropical grassland at Kurkshetra, India. Ecological Monographs 44: 351-376.

U.S. Geological Survey 1974. Methods for Collection and Analysis of Water Samples for Dissolved Minerals and Gases. U.S. Geological Survey, Washington, D.C., USA

Walkley, A.J. \& I.A. Black 1934. An examination of method for determining organic carbon and nitrogen in soil. Journal of Agricultural Science 25: 589-609.

Willard, H.H., L.L. Merritt \& J.A. Dean 1974. Instrumental Methods of Analysis, 5 ${ }^{\text {th }}$ edn. D. Van Nostrand Co., New Jersey, USA. 